\title{
INTERNATIONAL LAW AND EXTRATERRITORIAL APPLICATION OF THE ANTITRUST LAWS
}

\author{
GEORGE WINTHROP HAIGHTT
}

In the absence of a clear legislative intent to the contrary, the courts of this country will apply and enforce the principles of public international law.2 One such principle is that the penal laws of a nation cannot "extend beyond its own territories, except so far as regards its own citizens." " The United States, Great Britain, France, and a majority of other civilized States recognize that the jurisdictional competence of a State is governed by this territorial principle. ${ }^{3}$ A court may, however, in ignorance or disregard of this principle, seek to punish a foreigner, over whom it has obtained jurisdiction according to its own rules, for alleged acts that have been performed abroad. Noreover, in many States an exception to the territorial principle is recognized where an offense has been committed abroad against the security, integrity or independence of the State. ${ }^{4}$ No such "protective" principle, how-

$\dagger$ Member, New York Bar. The author gratefully adinowledges the contributions to this article which have been made by Sir Valentine Holmes, Q.C., Inner Temple, London, and Professor Otto Kahn-Freund of the London School of Economies.

1. "[A]n act of Congress ought never to be construed to vivlate the law of nations if any other possible construction remains. . . " The Schooner Charming Betsy, 2 Cranch 64, 118 (U.S. 1804). Also see, MAawwer, Interspretation of Statures 152 (9th ed. 1946). For an interesting discussion of the new Netherlands constitutional provisions relating to the supremacy of international agreements, see van Panhuys, The Ncthcrlards Constitution and International Lan, 47 AMr. J. Ist'. L. 537 (1953).

2. Story, J., in The Apollon, 9 Wheat. 362, 370 (U.S. 1824). See 1 Hyos, I:siresNational. LaW Chiefly as Interpreted and Applied by the Umited States 726-30, S04-09 (2d ed. 1945) ; 2 MIOORE, A Digest of International Lnw 236 (1906) ("There is no principle better settled than that the penal laws of a country have no extraterritorial force."). Also see Story, Commientaries on the Conflict of Laws 20-22 (7th ed. 1872).

3. "A country is no more entitled to assume jurisdiction over foreigners than it would be to annex a bit of territory which happened to be very convenient for it." Lord Finlay, in The Case of the S. S. "Lotus," P.C.I.J. Ser. A, No. $10 / 9$ p. 56 (1927). See also the opinions in this case of Judges Loder (pp. 34, 35), Weiss (p. 44), Nyholm (p. 63), Moore (pp. 92-4) and Altamira (p. 95); STORY, op. cit. supra note 2, at 767-9; Wheaton, Eleatents of International LaW 270-4 (6th Eng. ed, Keith, 1929); Oppenheiss, Interenational LaW 298-302 (7th ed, Lauterpacht, 1948); IE Vadnes, Intzodlction A L'Etlde du Drolt Pen.ll International 438-58 (1922) and Les Prdncipes Modernes Du Droit Penal Intennational 11-13 (1923); Research in International Law under the Auspices of the Harvard Law School, Jurisdiction arith Kesfect to Crime, 49 Axr. J. INT'L L. Supp. $480-4$ (1935) (hereinafter cited as Harvard Research); Hanbury, The Territorial Limits of Criminal Jurisdiction, 37 Pror of Pum nas Prrvate Int'l Law, The Grotius SocieTY 171 (1952); Beckett, The Exercise of Criminal Jurisdiction over Foreigners, 6 BRIT. Y.B. INT'L L. 44 (1925); Criminal Juristiction ceer Foreigners, 8 BRIT. Y.B. INT'L L. 108 (1927).

4. Harvard Research, supra note 3, at 543-61. 
ever, is recognized by the United States or Great Britain. On the other hand, the United States, Great Britain and many other countries accept an "objective" application of the territorial principle: a State may exercise penal jurisdiction over a foreign national in certain types of cases where a consummating act within the State's territory was a constituent element of a crime committed abroad. ${ }^{5}$

Extraterritorial application of American antitrust laws, as currently sought by the Department of Justice and recognized in recent court decisions, conflicts with public international law. The conflict arises whenever an American court attempts to prosecute and punish foreign nationals for their acts performed outside the territorial limits of the United States which, if performed within such limits, would violate the antitrust laws. Whether or not an American court is competent, under public international law, to punish them for their acts abroad depends on the applicability of the territorial principle to antitrust prosecutions; and, if the territorial principle does apply, whether or not an "objective" application is permissible or the "protective" principle may be applied.

\section{The Territorial Principle and the Antitrust Laws}

The territorial principle is applicable to Sherman Act prosecutions because these proceedings are penal. ${ }^{b}$ The distinctions which prevail in the United States between criminal and civil proceedings under the Sherman Act-between indictment and subsequent fine or imprisonment, on the one hand, and a bill in equity and subsequent injunction or order compelling the disposition of property or perhaps reconstruction of an industry, on the other-are not relevant in determining whether the proceedings are penal in the international law sense. What are civil proceedings under the municipal law may be, and usually are, highly penal. While criminal proceedings carry the stigma of indictment, finger-printing and conviction, civil proceedings may result in shackling a company in perpetuity with the fetters of a decree forbidding it to do a great many things. Since the decree may be difficult to interpret, a wide range of company behavior will be subject to the constant peril of a prosecution for contempt. In addition to this, orders may be issued requiring the company to divest itself of valuable property which it holds abroad, to

5. Id. at $487-503$.

6. See Sections 1 and 2 of the Sherman Act, 26 STAт. 209 (1890), 36 STAT. 1167 (1911), 50 Srat. 693 (1937), 15 U.S.C. $\$ \$ 1,2$ (1946). Although the discussion which follows will relate primarily to these sections, the principles apply with like force to other penal provisions of the antitrust laws.

The offenses that are proscribed by this Act are criminal offenses in the sense that they are public wrongs which may be redressed at the instance of the State in proceedings which have as their objective the infliction of punishment or the impositions of penalties remissible only by the State. See Kenny, The Nature of a Crime in Tumnes, KENNY'S OUTLINE OF CRMMINAL LAW 530-46 (16th ed. 1952). 
alter contracts, to license patents, and to grant patent immunities.7 Orders such as these and injunctions which forbid the performance of contracts made abroad and valid by the laws of the States where they are made clearly constitute an interference with the internal trade and commerce of foreign states which it is the purpose of the territorial principle to avoid. ${ }^{8}$

In United States $v$. Alumimum Company of America (Alcoa), ${ }^{8}$ Judge Hand asserted jurisdiction over cartel agreements made abroad by foreign companies, the American company not being a party to them. He said that these agreements, notwithstanding their completely foreign nature, were unlawful because "they were intended to affect imports and did affect them," and because "any state may impose liabilities even upon persons not within its allegiance, for conduct outside its borders that has consequences within its borders which the state reprehends." 10

7. See e.g., United States v. Imperial Chemical Industries, Ltd, 105 F. Supp. 215, 220 (S.D.N.Y. 1952) ("Our objective is to fashion ... means by which the agreement found to exist is terminated, its revival prevented and its effects destroyed. . . .) (emphasis added). In United States v. General Electric Co., 115 F. Supp. 835, 851, 852, 87S (D.N.J. 1953), however, the court excepted Philips, the Netherlands compiany, from provisions for access to records other than those located in the United States. The reason given for the exceptions was the possibility of "international complieations." The court also refused to require Philips to grant immunities involving foreign patents.

8. Decrees on these lines, when applied to property owned by foreigners abroad, have provoked courts and governments to protest in vigorous terms. Judge Ryan's order in the $I C I$ case, compelling the dismemberment of a Canadian company with Canadian shareholders as an alternative to divestiture of stock in the Canadian company by one defendant company or the other, was described by an important Canadian newspaper as "sheer effrontery," "American judicial arrogance," "incredible" and "irressansible." The Globe and Mail, Toronto, Aug. 20, 1952, p. 6, col. 1.

More recently, the Department of Justice, in the grand jury investigation of the international oil industry, attempted to subpoena correspondence, files, and other documents of the Anglo-Iranian Oil Company, an English concern, relating to a vast ficld of activity outside of the United States. In re Investigation of World Arrangements with Relation to the Production, Transportation, Refining and Distribution of Petroleum in Possible Violation of Title 15 U.S.C. Sections 1-23: Míse. No. 19-52, D.D.C., 1952. The British Government directed the officers and directors of that company not to produce the documents, considering the subpoena to be contrary to international comity. Transeript of Record, Investigation, supra, at 386. See also id. at 509, 595-667, 734-753, 759-773. Prohibitions were also issued by the Governments of the Netherlands, France, India, and Pakistan. Id. at $570,730,731,756$. Belgium is not referred to in the Transeript, but the government of that country issued prohibitions.

Also see, Fletcher-Cooke, Risk of Applying American Anti-Trust Low to Middle East Oil in The Daily Telegraph, London, Nov. 20, 1952, p. 6, cols. 3-5, which stated in regard to the above investigations that: "However bachward and benighted the C'nited States may think the rest of the world is over the matter of munopolies and restraints of trade, the truth is that she cannot, even if she wants to, enforce her sincere and dec" convictions upon countries whose outlook is entirely different." See also Comisty as:d the Oil Companies, 165 THE Econonist 556 (1952).

9. 148 F.2d 416 (2d Cir. 1945).

10. Id. at 443. The Agreements referred to were, tirst, an Agreement made in Paris in 1931 to which all parties were foreign companies and which did not talse imports 
More recently, Judge Ryan in United States v. Imperial Chemical lndustries (ICI) 11 deemed the law to be "crystal clear: a conspiracy to divide territories, which affects American commerce, violates the Sherman Act."12 But his orders directing disposition of industrial property abroad were disregarded by the Court of Appeal in England because they were an attempt to "assert an extra-territorial jurisdiction which the Courts of this country cannot recognize. ..."13 Referring to the statement in Judge Ryan's opinion that "it is not an intrusion on the authority of a foreign sovereign for this court to direct that steps be taken to remove the harmful effects on the trade of the United States,"14 the Master of the Rolls said:

"If by that passage the learned Judge intended to say (as it seems to me that he did) that it was not an intrusion on the authority of a foreign sovereign to make directions addressed to that foreign sovereign or to its courts or to nationals of that foreign Power effective to remove (as he said) 'harmful effects on the trade of the United States', I am bound to say that, as at present advised, I find myself unable to agree with it." 15

The Alcoa and $I C I$ cases evidence a basic misconception regarding the international law competence of the United States to proceed against foreign

into the United States into account in fixing production and distribution quotas; second, a 1936 Agreement, also made abroad between the same parties, which provided for the payment of royalties in respect to production exceeding free quotas. There was no reference in the 1936 Agreement to imports into the United States, and the district court found that only the Canadian company counted shipments to that country as part of its production quota. 44 F. Supp. 97, 285 (S.D.N.Y. 1941). Judge Hand held, however, that the general restriction on production outside the United States, at which the 1936 Agreement was directed, evidenced a clear intent to affect imports into the United States and that the burden was on the defendants to prove that there was no such effect. As they failed to sustain this burden, the Agreement of 1936 was found to violate section 1 of the Sherman Act. In the district court, Judge Caffey had said that all parties were agreed that the question was whether or not the foreign combination was "to so operate in this country as to directly and materially affect our foreign commerce." Id. at 283. He held that the burden was on the Government to prove such direct and material effect and that they had not sustained the burden.

11. 100 F. Supp. 504, final order entered, 105 F. Supp. 215 (S.D.N.Y. 1951).

12. United States v. Imperial Chemical Industries, Ltd., 100 F. Supp. 504, 592 (S.D.N.Y. 1951) (emphasis added).

13. British Nylon Spinners Ld. v. Imperial Chemical Industries Ld., [1953] 1 Ch. 19, 24.

14. United States v. Imperial Chemical Industries, Ltd., 105 F. Supp. 215, 229 (S.D.N.Y. 1951). The court in framing the decree stated that "3. No provision of this judgment shall operate against ICI for action in compliance with any law of the United States Government or of any foreign government or instrumentality thercof to which ICI is at the time being subject and concerning matters over which under the law of the United States such foreign government or instrumentality thercof has jurisdiction." Quoted in British Nylon Spinners Ld. v. Imperial Chemical Industries Ld., [1953] $1 \mathrm{Ch}$. 19 n. 4.

15. British Nylon Spinners Ld. v. Imperial Chemical Industries Ld., [1953] $1 \mathrm{Ch}$. $19,24$. 
nationals under the antitrust laws. If a State can take jurisdiction over acts committed abroad by foreigners because they have "consequences" within its territory and it "reprehends" such acts, the door is open to an almost unlimited extension of extraterritorial jurisdiction. That foreign nationals are answerable for their acts within the territory of the United States is beyond question, but to prosecute them for what they do abroad can be justified only if an objective application to the territorial principle is permissible, or if a valid exception to that principle is applicable. Unless "consequences" and "harmful effects" mean "constituent element of a crime," which might permit an objective application, these decisions are contrary to international law.

\section{Objective Application Nor Permissible}

Even if Judges Hand and Ryan were relying on the objective application of the territorial principle, this exception to the strict rule of territoriality is of limited scope, ${ }^{16}$ and would not extend to Sherman Act violations. The Lotut $^{17}$ is the leading case in international law in which such an application has been involved. There a collision, outside territorial waters, between a French and a Turkish vessel, caused the loss of the latter and the death of eight Turkish nationals. When the French ship arrived at Constantinople, its officer in charge of the watch was tried and convicted of involuntary manslaughter. The French and Turkish governments agreed to submit to the Permanent Court of International Justice the question whether Turkey had "acted in conflict with the principles of international law" in prosecuting the French officer. The Court decided in favor of Turkey on the ground that the crime had been committed in Turkish territory (the Turkish vessel) notwithstanding the fact that the French officer had at all times remained on board the French vessel. The case is authority for the proposition that a

16. John Bassett Moore has emphasized that in no case had an English or Amcrioan court assumed jurisdiction "even under statutes couched in the most general languge, to try and sentence a foreigner for acts done by him abroad, unless they were braught, either by an immediate effect or by direct and continuous causal relationship, within the

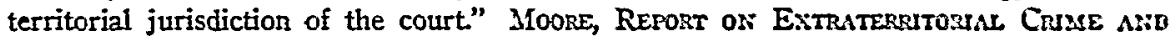
InE Cuttixg CASE 34 (1887). The effect being indistinguishable from the act, each has been said to constitute an "essential constituent element" or "part" of the crime, thus justifying the exercise of territorial jurisdiction. Harvard Research, stspra note 3 , at $480,494,495$. In the Lotis case, the Permanent Court of International Justice pointed out that the two elements of the offense-the act of negligence or imprudence which had its origin on the French ship and the effect felt on board the Turkish ship-were "legally, entirely inseparable, so much so that their separation renders the offense non-existent." The Case of the S.S. "Lotus," supra note 3, at 30. The assumption that "the place where the effect is produced is the place where the act was committed is in every case a legal fiction" and is only justified "where the act and its effect are indistinguishable." Id. at 37 (M. Loder).

17. Case of the S. S. "Lotus," supra note 3. See 2 HACEworth, Digest of Iriternational Law 193-6 (1941); 1 Pitt Cobbett, Cases on International Lay 250-3 (6th ed. 1947). 
State has competence to punish a foreigner for his acts abroad if such acts form a constituent element of a crime consummated within the territory of the State. ${ }^{18}$

It is, however, clear from the opinions in The Lotus that an objective application of the territorial principle is only permissible when not only is the consummation or "effect" inseparable from the act committed abroad but the offense is one which the community of civilized nations has come to regard as justifying a modification of the strict territorial principle. In the case of antitrust violations, there are several features which distinguish such offenses from those so regarded by the community of civilized nations.

In the first place, taking the Sherman Act as the example, violations of Sections 1 and $2^{19}$ do not fall within any category of crimes which are common to such community; they are offenses created by Congress for the purpose of better regulating commerce between the states and with foreign nations, and they express the public policy of the United States on American trade and the American economy. Not even such a policy, let alone the "crime" itself, is common to other civilized societies. It is significant that no mention of this type of economic crime has been made in comprehensive comments in this country on the objective application of the territorial principle. ${ }^{20}$ Incleed, condonation of such a "crime" by foreign nations is not a subject for pro-

18. See Willians, Chapters on Current Internationat Law and the League of Nations 209 (1929) ; Brierly, The "Lotus" Case, 44 L.Q. Rev. 154 (1928); Comment, 37 YALE L.J. 484 (1928). Judge Moore's dissent was limited to the proposition that Article 6 of the Turkish Penal Code was contrary to international law as it asserted penal jurisdiction over foreigners for acts committed by them outside Turkey "to the prejudice ... of a Turkish subject." The Court had refused to consider this question on the ground that it was not included in the compromis. The Case of the S. S. "Lotus," supra note 3 , at $23,24,89-93$.

The contention of Turkey that its competence must be presumed until a rule of international law prohibiting it could be established by France was supported by only a minority of the permanent members of the Court and was severely criticized in the separate opinions. See Williass, op. cit. supra, at 215-22; Brierly, The Law of NATrows 52, 53 (4th ed. 1949).

19. 26 Stat. 209 (1890), 36 Stat. 1167 (1911), 50 Stat. 693 (1937), 15 U.S.C. $\S \S 1,2$ (1946).

20. 1 HYDE, op. cit. supra note 2 , at 804-13; Cook, The Application of the Criminal Laze of a Country to Acts Committed by Foreigners Outside the Jurisdiction, $40 \mathrm{~W}$. VA. L.Q. 303 (1934); Harvard Research, supra note 3, at 487-506. After stating that there must be "a close and definite connection" between the act and the prosecutor, Hyde says the "connection is . . . apparent when the act of the individual is one which the law of nations itself renders iuternationally illegal or regards as one which any member of the international society is free to oppose and thwart" (emphasis added), 1 Hrve, op. cit. supra, at 804, 805; neither test can be satisfied in the case of antitrust law offenses. Even if the international community should eventually agree that the emphasis should be on the prevention of conduct regarded as "anti-social" and on the detention of culprits, so that the place where the crime is committed assumes less importance, Prof. Cook still adds: "Clearly not all kinds of so-called 'criminal acts' ought to be dealt with on the 'cosmopolitan' theory ... the mere fact of living together in groups makes it necessary at all times and in all places to fix upon a certain number of types of conduct 
test. ${ }^{21}$ Even in the few instances where there is foreign legislation patterned after the Sherman Act, there is little similarity between the law as it has developed in the United States and the law in the countries which have such legislation. ${ }^{22}$

Although the Sherman Act purported originally to codify the common law, our interpretation of restraint of trade has varied widely from that in other English common law countries. Thus, the highest court in the British Commonwealth was "not aware of any case in which a restraint though reasonable in the interests of the parties has been held unenforceable because it involved some injury to the public."23 It has long been established in England that if the restraint has been imposed in good faith and for the protection of legitimate trading interests it is lawful even though it may be harmful to third parties. ${ }^{24}$

Nor are there any statutory prohibitions in England. The Monopolies and Restrictive Practices Commission at the instance of the Board of Trade investigates and reports what effect certain practices may have on the public interest ${ }^{25}$ and although it is developing a series of cases which may serve to limit the common law freedom of traders to combine or agree upon restrictive practices, ${ }^{26}$ it is readily apparent from these cases and from the

which must be checked if group life is to continue. Very possibly attempts to apply a 'cosmopolitan' theory of crime ought to be limited to types of conduct of this general character." Cook, supra, at 329.

21. Although the grant of a monopoly is "inconsistent with American ideas and would probably be prejudicial to American interests, any official protest against it, unless based upon treaty obligations, would necessarily have the appearance of attempting to interfere with the sovereign right of a country to regulate its own export and import trade" 2 Moore, op. cit. supra note 2, at 77 (quoting Secretary of State Foster).

22. The laws of other countries are collected and discussed in RESTICTNE BLstitiss Practices, (Economic and Social Council, United Nations) (E/2379, E/2379/Adds. 1, 2, E/AC/37/2, E/AC. 37/2/Adds. 1, 2 April 29, MFarch 13, 1953) ; Refozs or THE Dep.ATt-

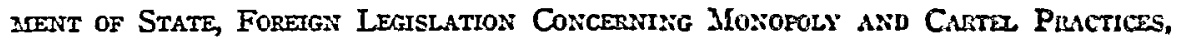

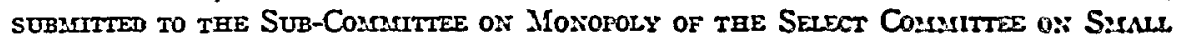
Business of the UnIted States Senate, (July 9, 1952).

23. Attorney-General of the Commonwealth of Australia v. The Adelaide Steamship Company, Limited [1913] A.C. 781, 795.

24. Miogul Steamship Company Limited v. MícGregor, Gow \& Co., 21 Q.B.D. 544, 553, 554 (1883), aff'd, 23 Q.B.D. 598 (C.A. 1899), [1892] A.C. 25; Attorney General of the Commonwealth of Australia v. The Adelaide Steamship Company, Limited, [1913] A.C. 781; North Western Salt Company, Limited v. Electrolytic Allali Company, Limited [1914] A.C. 461; Comment, The British Jlonopolies Act: A Contrast werith Americair Policy and Practice, 59 Yale L.J. $\$ 99$ (1950).

25. Monofolies and Restrictive Practices (Imquiry ajid Control) ACT, 1948, 11 \& 12 Geo. $6 \mathrm{Ch}$ 66. See Comment, The British Monopolies Act of 1948, suppo note 24.

26. See, e.g., Report of the Supply of Dental Goons (November 3, 1950), and The Monopolies and Restrictive Practices (Dental Goons) Ornez (1951), which came into operation on July 30, 1951; RefOST ON THE Supply of CAST Iros Rurwwaten Goods (February 16, 1951); Report on tre Supply of Euectasc Lasirs (August 31, 1951); Report on the Supply of Ixsuzated Electric Wires and Cables (April 25, 1952); Report on the SUPply of Insulur (July 31, 1952); Reroms u: tae SupfL 
debates in Parliament that the "crimes" of the Sherman Act are not regarded as crimes in England, and that there are fundamental differences in the criteria of reasonableness and protection of the public interest. ${ }^{27}$

The Australian Act of $1906^{28}$ was modelled on the Sherman Act, but it was soon held by the Privy Council that a detriment to the public was not to be presumed from the fact that an agreement was in restraint of trade. ${ }^{20}$ In ascertaining whether a detriment to the public had been intended, workers and producers were considered as much a segment of the public as consumers, and in the long run the interests of all segments were cleemed to be the same, namely, to maintain the flow of goods. An intention, therefore, to achieve this end by combining to raise prices and limit production for the benefit of the workers and producers was not unlawful. Accordingly "the Australian economy has become one of controlled and rationalized competition in which private restraints of trade have become rather general." 30

In Canada two types of action have been made offenses by statute: a conspiracy to prevent or lessen competition unduly, and a merger, trust, or monopoly which has operated, or is likely to operate, against the public interest. ${ }^{31}$ Although the law has been interpreted by the Canadian courts as designed "for the protection of the specific public interest in free competition,"32 illegal conspiracies must involve "undue" restraints, and public detriment is an essential pre-requisite to condemnation either of a conspiracy or of a merger, trust or monopoly. Penalties can be inflicted only in the form

and Export of Matches and the Supply of Match-Making Machinem (October 2, 1952) ; Report on the Supply of Imported Timber, (July 23, 1953). Sanctions can be applied whenever the Commission reports, or the House of Commons resolves, on the basis of a Commission report, that existing practices operate against the public interest, and an order has been approved by both Houses of Parliament. Thus far, only an order relating to the Dental Goods industry has been issued.

27. See Dame Alix Kilroy, Address to Manchester Statistical Society, reported in The Manchester Guardian, March 12, 1953, p. 4, col. 3; Kilroy, The Task and Methods of the Monopolies Commission, 43 Progress, The Magazine of Unilever 125 (1953); Rostow, Britain and Monopolies-An. Anerican View, The Manchester Guardian, Feb. 16, 1953, p. 4, col. 6-7; The Structure of Industry and the Technical Revolution, 19 Planning No. 350 (1953); The Monopolies Commission, 19 Planning No. 353 (1953).

28. Australian Industries Preservation Act 1906 entitled "An Act for the preservation of Australian industries and for the repression of destructive monopolies."

29. Attorney-General of the Commonwealth of Australia v. The Adelaide Steamship Company, Limited, [1913] A.C. 781, affirming [1912] 15 C.L.R. 65, reversing [1911] 14 C.L.R. 387.

30. Report of the DepartMent of State, op. cit. supra note 22, at 117. In the State of New South Wales, Section 7 of the Monopolies Act of 1923 states: "Any combination of producers of any commodity which is reasonably necessary for the maintenance of the industry of such producers shall not be deemed to be to the detriment of the public." Id. at 122 .

31. Section 498 of the Criminal Code, R.S. 1927, c. $36, \S 498$; and $\$ \S 2(1), 2(4)$ and 32 of the Combines Investigation Act, R.S. 1952, c. 314.

32. Container Materials Limited v. The King, [1942] S.C.R. 147, 152. Sce also Reg. v. McGavin Bakeries, [1952] 1 D.L.R. 201, 207. 
of fines or imprisonment or both; there is no procedure comparable to the civil suit under the Sherman Act. And while there have been many conspiracy cases, there have been only two cases in 43 years under the monopoly provisions. ${ }^{33}$

In addition to the considerable disparity in this type of legislation within the British Commonwealth. ${ }^{34}$ other countries have failed to agree on the nature and treatment of the offense. ${ }^{35}$ There are statutory prohibitions in some countries and regulatory measures in others, but in none has any jurisprudence developed which in any substantial way resembles that of the United

33. For discussion of the Canadian legislation see the Reronr of TnE Depurtareat of STATE, op. cit. supra note 22, at 101-117. One essential difference is that price-fixing agreements are not illegal per se in Canada; they are illegal only if they are proved to be detrimental to the public interest: this may be established by proof that the result has been the elimination of competition over a substantial area of the market. Resmictrve Business Practices, op. cit. silpra note 22, at 21 .

34. In the Union of South Africa, the proposed Regulation of Monupolistic Conditions Act would define monopolistic conditions and provide for investigation to ascertain whether they exist. If they are found to exist and to be detrimental to the public interest, the case may be referred to the Minister of Economic Affairs. He might then require any party to terminate the arrangement, to cease to be a prasty, or to reirain from exercising an offensive practice, or he might declare the monopulistic condition unlawiul and require its dissolution.

In NTew Zealand, The Commercial Trusts Act, 1910 (1910, No. 32) applies to a limited number of commodities and bans particular types of practices: rebates or concessions for exclusive dealing ( $(3)$, refusing to deal with a persnn who dines not restrict his dealing or who refuses to join a commercial trust $(\S 4)$, and conspiring to monofylize contrary to the public interest $(\$ 5)$. It also forbids "unreasomably high" prices charged by members of commercial trusts or persons acting pursuant to their dircetions $(\S 6)$. There have been no prosecutions since 1930, and only a few prior to that date. RErost of The Departaient of State, op. cit. supra note 22, at 124-31.

There is no legislation relevant to this subject in Pakistan or Ceylon. India has not dealt specifically with the subject. See Restrictrve Business Practices (E/2379/Add. 2, Annex C), op. cit. sipra note 22, at 101.

35. In European countries other than France there are fev outright prohibitions, since it is recognized that combinations and restrictive arrangemunts may be in the public interest. In Sweden resale price maintenance and collusion in tenders are prohibited unless the "Freedom of Commerce Board" grants permission. Laws of June 29, 1946 and September, 1953. In Norway and Denmark the subject forms part of overall price control. RePORT of THE Departarent of STATE, op. cit. supro note 22, at 68-75, 62-S; NomWegtar LAw of JULy 25,'1953. A proposed new law in the Netherlands combines compulsory registration with provisions for investigations, but there are no prohibitions. Bill No. 2 and Explanatory Memorandum, submitted to States General November 24, 1953. Beigian law is favorable to the formation of cartels. The emphasis is on protecting the freedom of those who do not wish to enter the cartel, and on cheching abuses contrary to the interests of the parties concerned or, where there are concentrations of prependerant economic power, abuses contrary to the public welfare. Refort or THE Derafraserir of STATE, op. cit. supra, at 15-18; for proposed new law, see Productivite, Brussels, December, 1953, p. 15. Austria deals with the matter by registration. Reroms of TuE DEPARTARENT of State, op. cit. supra, at 6-11. Switzerland has no legislation designed specifically to combat restrictive agreements, although a 1947 amendment to the Constitution 
States. For example, since 1810 the Penal Code of France has made it a criminal offense to cause an artificial enhancement in price by collective action. The courts, however, refused to apply the law to prevent the recovery of "normal" profits, and since an amendment in 1926 the law has been regarded as applicable essentially to "excessive speculation."

There is a second fundamental distinction between a Sherman Act offense and the type of crime to which the objective application of the territorial principle has been invoked with the sanction of the international community. While in objective application cases the proximity of cause and effect is direct and readily ascertainable, the Sherman Act offense is complex, and it is usually difficult to establish the relationship of cause and effect. When foreigners agree abroad to fix prices, to limit production, to allocate territories or otherwise "restrain trade" (in the United States sense), they may have no intention or expectation that their arrangements will operate in the United States; as in the case of the Phoebus Agreement ${ }^{37}$ or the Swiss aluminum cartel, ${ }^{38}$ they may even exclude the United States from the operative provisions. Nevertheless, the foreigners may find themselves charged in the

paves the way for legislation "in derogation, if necessary, of the principle of freedom of trade and industry." Id. at 59. What legislation will finally emerge in Germany and Italy is still uncertain.

In Latin America the subject is not considered of importance. Id. at 154. In Argentina drastic legislation on the subject of monopolies "has been to some extent forgotten" and there seems to be no desire to enforce it, $i d$. at 157 , although some cases were brought under an earlier law, id. at 158-9; in Brazil "restrictive business practices are buried together with petty malfeasances and little regard for their importance is evident," id. at 161 ; in Mexico legislation "has had little effect upon the suppression of monopolies or the discouragement of restrictive business practices," $i d$. at 169 .

36. Id. at 20-23. The original Article 419 punished combinations which held goods off the market or sold only at a certain price, or artificially raised or depressed prices. The modified version in effect since 1926 punishes all those who, individually or collectively, take action in the market "for the purpose of procuring a profit which would not be the resuit of the natural operation of the law of supply and demand" or who bring about an artificial change in prices. Thus, it is no longer the combination or "entente" as such which is the offense: it is action, individual or callective, in the market with a view to abnormal gain. This is no longer "antitrust."

In August, 1953, the Council of Ministers issued a decree prohibiting (with certain exceptions) collective action hindering cost reductions, furthering pricc increases, maintaining minimum prices, unjustified discriminations in price increases or in meeting demands for products or services. DECREE No. 53-704 (August 9, 1953), amending the Price Ordinance of June 30, 1945, No. 45-1483. An impartant exception to these prohibitions is where the parties can show "improvement and expansion of outlets of production" or can "assure the development of economic progress by rationalization and specialization."

37. For this and related agreements governing the distribution of electric lamps abroad, see United States v. General Electric Co., 82 F. Supp. 753, 828-48 (D.N.J. 1949). See also REPort on THE Supply of Electric LaMrs, op. cit. supra note 26, at 126-51.

38. The Canadian company, Aluminium Limited, endeavored to include the American market in the 1931 Agreement, but European members of the cartel refused and shipped metal to the United States. Shipments to this country were included in determining 
United States with a criminal offense which they could hardly have been expected to foresee or to understand. ${ }^{39}$ This is quite different from the comparatively simple cases of $A$ shooting at $B$ across a border, or of one ship colliding with another and causing the death of some of its crew, or of arranging in one country to obtain money by false pretenses in another, or of sending poison from one country to another, or from the many other cases to which the territorial principle has been objectively applied. ${ }^{* 0}$ In an antitrust case. it is necessary to trace economic consequences which radiate from an act or a complex of acts abroad into and through many different markets and territories. The more extensive these consequences are, the more difficult it becomes to identify them as they combine with, and are submerged by, consequences radiating from other acts, conditions of supply and demand, tariff barriers, currency controls, government quotas and subsidies, and the perils of war or economic strife.

A third reason for excluding the Sherman Act offense from the objective application of the territorial principle lies in the vague and uncertain nature of the Act's prohib:-ions. Not even American lawyers can always forecast its application. To the foreigner it would be an intolerable burden to require him or his lawyers to understand the intricacies of the case law under the antitrust statutes, to prognosticate whether the rule of reason applied to his activities in his own country or that what he did was a per se violation; and, if the rule of reason did apply, to forecast the mental processes of an American judge educated and living in a political and economic climate fundamentally different from his own. By its very nature this type of legislation is replete with uncertainty and unsuited to extraterritorial application. ${ }^{11}$

Fourth, if international law were to permit an objective application in the case of antitrust laws such as the Sherman . Act, it would open the door to interference with freedoms and liberties guaranteed by other nations. This

royalties under the 1936 Agreement, but there vas no agreement not to malse such shipments. The Agreement did not relate to production in the Cinited States or to sale; there United States v. Aluminum Company of America, 44 F. Supp. 97, 2S0-5 (S.D.N.Y. 1941).

39. It appears to be Judge Learned Hand's view that the foreigner acts at his psril when be can foresee consequences within the United States. See text at note 10 sigro. Claudy, Sherman Anti-Trust Law: Applicability to Foreign Commerce, 37 Conures L Q. 821 (1952), taking the matter to its logical conclusion, says that "it is difficult to imagine any association of even potential, unestablished competitors that might nit produce, from within or without the United States, a proscribed effect upon United States export or import trade." Id. at $\$ 25 \mathrm{n} .25$.

40. The cases in which the territorial principle has been "objectively" applicd are reviewed in Harvard Research, supra note 3, at 487-503. Sce also Cook, sulra note 20. But see Timberg in Oppenheim, Nerenberg, Diggens, \& Timberg, The lunfoct of the Anti-Trust Laüs on Patents and Trade-Marl in Foreign Commerce, 21 Gro. Wasu. L. Rev. 663 (1953) ; Weisner, 4 Half Contury of Jurisdictional Derelopsucul: I'rom Baranas to Watches, 7 Minani L.Q. 400,403 n.1 (1953).

41. See Wolf, La Legislation Antitrust des Etats-Unis et ses Lffets Intennotionanx, 2 Retue Internationale De Droit Cosiparé 440, 475 (1950). 
was a concern expressed in the Cutting case in which an American citizen was tried, convicted, and imprisoned in Mexico for publishing in the United States a libel against a Mexican. ${ }^{2}$ There the liberty in question was freedom of speech $:^{43}$ in the case of the extraterritorial application of laws regulating trade it is freedom of trade and freedom of contract. For example, as noted above, there is no law in England against combinations, collective boycotts or other restraints of trade ${ }^{44}$ on the contrary, the liberty of traders to combine and exclude other traders is a fundamental liberty which can be freely exercised in the absence of malice or some unlawful purpose. ${ }^{45}$ This is true in most other countries, particularly on the continent of Europe. ${ }^{40}$ Thus in Switzerland, the Federal Court has repeatedly stated that cartel agreements are protected by the principle of freedom of contract gutaranteed by the Civil Code. ${ }^{47}$

In any country, trade regulation or lack of it is determined by the judgment of that country as to what is best in its own public interest. Nations necessarily differ according to race, geography, climate, raw materials, and social and economic development. ${ }^{48}$ In many instances a highly competitive economy is considered wholly unsuitable, and combinations are regarded as essential. It is impossible to say that what may in this respect be in the interests of the American public must also be in the public interest of other civilized countries. So long as nations are independent, each one must determine for itself what is in the interest of its own public. In the absence of treaty or convention, therefore. there is no basis in international law or practice for

42. See Foreign Relations of the United States 751 (1887) ; 2 Foreign Rela toNs of the UNited States $1114-80$ (1888) ; 2 MoORE, A Digest of INTERNational. Law 228-42 (1906); Moore, Report on Extraterkitorial Crume and tile Cutting CASE 7-8 (1887).

43. See sources cited note 42 supra. Mexico asserted jurisdiction because the act of the accused was a penal offense in the United States as well as in Mexico. The United States protested that it was a violation of international law for Mexico to apply its penal laws to an offense "committed and consummated" by an American citizen outside Mexican territory, pointing out that if a country were permitted to exercise such jurisdiction it "would create a dual responsibility" in the foreigner, would "lead to inextricable confusion" and would be "destructive of that certainty in the law which is an essential of liberty."

44. Collective boycotts and exclusive dealing arrangements are subjects now under investigation by the Monopolies and Restrictive Practices Commission.

45. See sources cited note 24 supra.

46. Report of the Departasent of State, op. cit. supra note 22, at 15-20, 59-61.

47. Id. at 59-61.

48. In the absence of a precise definition, "public interest" is left "to mean what one wants it to mean according to the particular school of politics, economics, sociology, ideology, even theology to which one belongs." Sir Lynden Macassey, Q.C., quoted in Cartel, London, July, 1952, p. 6. In the debate last year in the Economic and Social Council it was pointed out that "cartels and combines could be the best or worst of institutions according to the use they made of their powers. ..." M. Masoin (Belgium), United Nations Official Records 243, 244 (Economic \& Social Council 16th Sess., 742d Meeting, July 30, 1953, Geneva). 
applying to this type of offense those rules which in the relations between States are accepted as justifying an objective application of the territorial principle. To permit each country to regulate the trade of foreign nationals in foreign countries on the pretext that its own trade is directly affected in a manner offensive to its own notions of public policy would make a travesty of the principle of sovereign independence.

\section{Inapplicability of the Protective and Universality Principles}

The United States does not accept the protective principle as a jurisdictional basis for punishing offenses committed by foreigners abroad against the security, integrity or independence of the State. ${ }^{49}$ Even the States which do accept this principle regard it as a linited exception to the territorial principle. Thus in France, where a foreigner may be prosecuted, either as principal or accomplice, for committing a crime against the safety of the State or for counterfeiting the State seal or national currencies, ${ }^{\text {to }}$ the territorial principle, with this exception, is vigorously applied. ${ }^{51}$ Moreover, a report of a subcommittee of the League of Nations states that the protective principle "relates to a very special class of crimes" and should be limited to "an agreed and uniform list" of acts which endanger a State's security. No such list has been prepared.

The assertion of the right to punish foreigners for their acts abroad has not, however, been limited to the principle of protection. The universality principle asserts a far wider competence: in effect it claims jurisdiction to punish aliens as well as nationals for any crime, committed outside as well as within the territorial limits of the prosecuting State. It is usually justified on the grounds that "crime is an attack on a law of justice common to all States, and consequently it concerns the public order of each of them; the State which has the delinquent in its power may therefore judge him; it is even its duty to do so, in virtue of 'international solidarity in the struggle

49. Harvard Research, supra note 3, at 543-63; $1 \mathrm{Hyds}$, op. cit. supro note 2, at 805-06: "Such legislation may be regarded as exceptional in character. Occasions for its application were formerly infrequent and attributable to circumstances indicative of great public need."

50. Art. 7 of the Criminal Code.

51. Moore, Report on Extraterritorial Crise, op. cit. supra note 42, at 54-6 and Appendix B (French court quashing the conviction of a Swiss citizen for larceny committed in Switzerland). See also, 2 Laws and Regurations on the Rzonse of the Higr SeAs 43 (United Nations, 1952).

52. Brierly, Criminal Competence of States in Respect of Offences Commilted oustside their Territory, Report of Couratrtee of Expersts for the Prognessive Codification of International Law, Publications of the League of Natjois, (V.Legal), V.7. C.50.MI.27 pp. 3, 4 (1926). See The Case of the S.S. "Lotus," supro note 3, at 45 (dissenting opinion of M. Weiss) ("To obtain its full force and to become a rule of international law," the protective principle would require "the general consent of the nations or a special convention.") 
against crime." "53 This is the view of many States whose legal systems have their origin in Roman Law, but it is recognized as a principle of international law only in the case of wrongs against the law of nations, such as piracy. The draft of The Convention on Jurisdiction with respect to Crime limited "universality" to certain crimes committed in places not subject to the at1thority of any State, and to crimes which were also offenses by the law of the place where they were committed, if the offender had been offered to the State of such place, and if the offer was unaccepted. ${ }^{\text {t4 }}$ Thus restricted, it is inconceivable that the United States would invoke the principle of universality as a justification for applying the antitrust laws to acts committed by foreign nationals in foreign countries.

\section{Treaties and Conventions}

That extraterritorial application of the antitrust laws is not a proper subject for unilateral action on the part of the United States is recognized by the State Department, if not by the Department of Justice. Since World War II, strenuous efforts have been made to obtain the adherence of other States to a convention for the international regulation of restrictive trade practices. ${ }^{55}$ Late in 1945, proposals put forward by the State Department to other nations for the "Expansion of World Trade and Employment" were incorporated into the Suggested Charter for an International Trade Organization adopted at Havana, and known as the Havana Charter. ${ }^{57}$ But the end product tempered the proposals' blunt prohibitions by the overall limitation that prohibited acts must "have harmful effects on the expansion of production or trade. ..." The Havana Charter, however, was never ratified by the United States Senate. More recently, the Economic and Social Council of the United Nations submitted to member states a modified proposal of that part of the Havana Charter which dealt with restrictive trade practices. ${ }^{68}$ The significance of this proposal lies in its recognition that this is a subject which requires treatment in the form of an international convention.

Since the War, United States' diplomatic activity in the field of trade regulation has been intense. A clause in condemnation of combinations which "may have harmful effects" has been incorporated into a number of bilateral

53. Quoted by Brierly, The "Lotzs" Case, 44 LAw Q. Rev. 154, 161 (1928).

54. Harvard Research, supra note 3, at 573-92.

55. See abA, Report of The Committee on International. Trade Regulation on Iarpact of Antitrust Laws on Foreign Trade 18-19 (Aug. 6, 1953).

56. See Internatronal Cartels-a league of Nations Memorandum 35,36 (United Nations, Department of Economic Affairs, U.N. Pub. No. 1948. II. D.2, 1947).

57. Final Act and Related Documents (United Nations Conference on Trade and Employment, Havana, Cuba, U.N. Pub. No. 1948. II. D.4, 1948).

58. U.N. OfFicial. Records, Economic \& Social Council, 16th Sess., 742d \& 744th Meetings (July 30,31, 1953); Resolution Relative to Report of the Ad Hoc Committce on Restrictive Business Practices, id. (Supp. No. 11). 
commercial treaties. ${ }^{69}$ However, it gives no right to the United States to prosecute the nationals of the other party to the treaty for arrangements made by them abroad which have harmful effects upon the commerce of the United States with that nation. The only right conferred is the right to require consultation, and it is left to the other nation to talie such measures as it deems appropriate, not as the United States may require. If the other nation refuses to take any measure, there is still no right conferred on the United States to proceed on its own. At the most, there is a breach of treaty for which damages might be claimed.

\section{Strict Applicition of the Territorial Principle}

Application of the antitrust laws to the citizens of other nations must, then, be confined to acts performed by them either within the territorial limits of the United States or at places which are, by international law, assimilated to such territory. And this principle must apply to "conspiracy" cases as well as other forms of criminal activity. The conspiracy itself, if entered into abroad, does not in the international law sense acquire a locus within the territory of the prosecuting state by virtue of the fact that overt acts may be committed therein. ${ }^{60}$ If the overt acts are themselves criminal, the state in which they occur may punish them as such, and proof of a foreign conspiracy may establish complicity in, and therefore liability for, such acts on the part of foreign conspirators. ${ }^{\text {e1 }}$ But if the crime is not one which the community of civilized nations has accepted as appropriate for the objective application of the territorial principle or the application of the protective principle, the foreign conspiracy itself, as in the case of any other crime completed abroad, remains outside the competence of the State.

There would be less confusion if the rule stated by Judge Caffey at the end of the trial in the Alcoa case were recognized:

"The vital question in all cases is the same: Is the combination to so operate in this country as to directly and materially affect our foreign commerce." 62

59. See e.g., Treaty with Italy, signed Feb. 2, 1948, in force July 26, 1949, Art. XVIII(3). For a discussion of this and other similar treaties see the ABA REPOsT, 0p. cit. supra note 55 , at $10,11$.

60. Cf. Reg. v. Boulton, $12 \mathrm{Cox} 87$ (1871) (English court had no juriseliction over a conspiracy in Scotland to commit a felony in England); Ford v. United States, 273 U.S. 593 (1927).

61. In France, acts of complicity abroad may be prosecuted when they constitute an indivisible part of the principal act performed in France. de Vannes, LES Paricufas Miodernes du Droit PÉxal International, op. cit. sigra note 3, at 44-6; 2 Travens, Le Droit PÉxal Isternational 492-523 (1921).

62. United States v. Aluminum Company of America, 44 F. Supp. 97, 283 (S.D.N.Y. 1941) (emphasis added). For the view that mere "effect on Amerian commerce" is enough, see Note, Application of the Antitrust Lanis to Extraterritorial Conspiracies, 49 YALE L.J. 1312, 1316-7 (1940). 
In all the cases cited by him to support this statement of the issue, the agreement made abroad actually did operate within the United States in the sense that it was partly performed there, the performance in every case being substantial. On appeal, however, Judge Hand substituted the far vaguer test of whether the act abroad "has consequences within" the territory. ${ }^{03}$ While admitting that in the earlier cases the foreign conspirators "had sent agents into the United States to perform part of the agreement," he dismissed this essential distinction on the grounds that "an agent is merely an animate means of executing his principal's purposes" and that the real test was whether the foreign conspiracy was "intended to affect imports and did affect them." This is hardly consistent with the principles of international law which have been discussed, or with the pre-war consent decrees in the foreign quinine, potash, and Norwegian sardine cases. These decrees recognized the territorial principle by providing:

“. . . that nothing herein contained shall be construed to restrain or prohibit any defendanit from doing any act or entering into any agreement which is entirely completed outside the United States and which does not require any act or thing to be done within the United States." 65

\section{CoNCLUSION}

A due regard for the sovereignty and independence of other nations in matters relating to their own trade thus requires restraint on the part of this country in attempting to impose its own methods of regulating trade and commerce outside its own territorial limits. It is a corollary of such regard that the United States has an absolute sovereign right, whether applied to domestic or foreign trade, to punish acts committed within its borders which constitute a breach of such regulations. However, the United States' desire to protect the foreign trade and commerce of American nationals, and even its complete conviction that its own laws and methods are the way of salvation for all the world, cannot justify an assertion of penal jurisdiction over the commercial activities abroad of the nationals of other countries.

63. United States v. Aluminum Company of America, 148 F.2d 416, 443 (2d Cir. 1945).

64. Id. at 444.

65. United States v. Amsterdamsche Chininefabriek, CCH, FEd. Trape ReG، Sknv. 4186 (S.D.N.Y. 1928) ; United States v. Deutsches Kalisyndikat Gesellschaft, id. at 4188 (S.D.N.Y. 1929) ; United States v. ABC Canning Co., id. at 4213 (S.D.N.Y. 1931). See Donovan \& McAllister, Consent Decrees in the Enforcement of Federal Anti-Trust Lanus, 46 HARv. L. Rev. 885, 924-5 (1933). For the more limited recognition of the territorial principle in the $I C I$ decree, see note 14 supra. 